\title{
Sekseverschillen in het verband tussen opvoedingsstijlen en delinquentie
}

Machteld Hoeve, Peter H. van der Laan, Jan R. M. Gerris en Judith Semon Dubas

\begin{abstract}
SAMENVATTING
In deze longitudinale studie zijn sekseverschillen onderzocht in het verband tussen opvoedingsstijlen en delinquent gedrag. Hiervoor werden bij 330 Nederlandse jongeren vragenlijsten afgenomen tijdens de adolescentie en de jongvolwassenheid. Ook werd een vragenlijst afgenomen bij de ouders van de jongeren. Moeders bleken verschillende opvoedingsstijlen voor zonen en dochters te hanteren; dochters werden vaker autoritatief opgevoed door moeders, zonen vaker toegeeflijk. Daarnaast werd er een significant interactie-effect tussen de opvoedingsstijl van de vader en sekse gevonden: zonen vertoonden vaker delinquent gedrag tijdens de adolescentie wanneer hun vader een verwaarlozende opvoedingsstijl in dezelfde periode hanteerde. Dochters waren vaker delinquent wanneer zij werden opgevoed door een vader met een toegeeflijke opvoedingsstijl. Bovendien vertoonden zonen relatief vaker delinquent gedrag tijdens de jongvolwassenheid wanneer hun vader een verwaarlozende stijl hanteerde tijdens de adolescentie.
\end{abstract}

\section{Inleiding}

Het is algemeen bekend dat jongens meer delicten plegen dan meisjes. De afgelopen jaren is er sprake van een toename van de geregistreerde criminaliteit door meisjes. Van 2006 naar 2007 steeg bijvoorbeeld het aantal processen-verbaal tegen meisjes met II.I\% en tegen jongens met 5.7\% (Ministerie van Justitie, 2008). De vraag is of deze toename een werkelijke stijging in het aantal gepleegde delicten door minderjarige

Dr. M. Hoeve is postdoc bij het programma Forensische Orthopedagogiek van de Afdeling Pedagogiek en Onderwijskunde van de Universiteit van Amsterdam. Contactadres: Universiteit van Amsterdam, Faculteit der Maatschappij- en Gedragswetenschappen, Pedagogiek en Onderwijskunde, Postbus 94208, 1090 GE Amsterdam. E-mail: m.hoeve@uva.nl.

Prof. dr. P. H. van der Laan is hoogleraar sociaal-pedagogische hulpverlening aan de Universiteit van Amsterdam en hoogleraar reclassering aan de Vrije Universiteit te Amsterdam.

Prof. dr. J. R. M. Gerris is hoogleraar gezinspedagogiek aan de Radboud Universiteit te Nijmegen.

Dr. J. S. Dubas is universitair hoofddocent op de afdeling Ontwikkelingspsychologie aan de Universiteit Utrecht. 
meisjes weergeeft of dat er andere mogelijke verklaringen zijn. Uit zelfrapportages onder Nederlandse jongeren blijkt namelijk geen toename van de meisjescriminaliteit (Van der Laan \& Blom, 2006). Op basis van eerder onderzoek kan in ieder geval worden geconcludeerd dat jongens meer en ernstiger delicten plegen dan meisjes en dat zij langer doorgaan met het plegen van delicten (Lenssen, Doreleijers, Van Dijk \& Hartman, 2000).

Tot op heden is het onduidelijk hoe het komt dat jongens meer delicten plegen dan meisjes. Een mogelijke verklaring is dat jongens en meisjes verschillend worden opgevoed en dat jongens gemiddeld hoger scoren op risicofactoren binnen het gezin, zoals een inadequate opvoeding. Een alternatieve verklaring is dat een minder adequate opvoeding meer van invloed is op delinquent gedrag bij jongens dan bij meisjes. In deze studie onderzoeken we of jongens anders worden opgevoed dan meisjes. Daarnaast onderzoeken we of er sekseverschillen zijn in het verband tussen opvoeding en delinquent gedrag.

Alvorens we de methode en resultaten van dit onderzoek bespreken, zullen we eerst nader ingaan op mogelijke verklaringen voor sekseverschillen in delinquentie en de invloed van de opvoeding door vaders en moeders. Daarnaast zullen we het begrip opvoedingsstijl toelichten.

\section{Verklaringen voor sekseverschillen in delinquentie}

Het feit dat jongens meer delicten plegen dan meisjes, is waarschijnlijk de reden waarom het onderzoek naar criminaliteit zich tot op heden voornamelijk heeft gericht op steekproeven met uitsluitend jongens of mannen. Het is onduidelijk hoe het sekseverschil in delinquent gedrag verklaard kan worden. Moffitt, Caspi, Rutter en Silva (200I) geven onder andere de volgende twee mogelijke hypothesen. De eerste hypothese gaat ervan uit dat het verschil in delinquent gedrag kan worden verklaard door een verschil in de etiologie voor delinquentie. Jongens en meisjes worden in dat geval wel beiden blootgesteld aan bekende risicofactoren voor delinquent gedrag, maar de aanwezigheid van deze factoren verhoogt het risico op delinquentie bij jongens doch bij meisjes niet of in mindere mate. Zo heeft eerder onderzoek bijvoorbeeld uitgewezen dat een slechtere band met ouders en dwingende en vijandige ouder-kindinteracties sterker samenhangen met delinquent gedrag bij jongens dan bij meisjes (Canter, I982; McFadyen Ketchum, Bates, Dodge \& Pettit, I996). Andere studies weerleggen dit echter (Webster Stratton, I996).

De tweede hypothese, die Moffitt de 'differential exposure hypothesis' noemt, gaat uit van het idee dat jongens en meisjes dezelfde risicofactoren hebben voor delinquent gedrag. Het verschil in de mate van delinquentie wordt hier verklaard doordat jongens meer worden blootgesteld aan risicofactoren dan meisjes. Een van de factoren die vaak worden genoemd als verklaring voor het sekseverschil in delinquent gedrag, is het verschil in opvoeding. Zo blijkt dat ouders over het algemeen meer toezicht houden op meisjes dan op jongens (Svensson, 2003). Tot op heden is het onvoldoende duidelijk hoe het sekseverschil in delinquent gedrag verklaard kan worden.

\section{Opvoeding door vaders en moeders}

Belangrijke risicofactoren van delinquentie liggen in het domein van het gezin, zoals 
een inadequate opvoeding. Er is veel onderzoek gedaan naar het verband tussen opvoeding en delinquent gedrag. Een onveilige gehechtheid, hard en fysiek straffen en weinig toezicht of supervisie door ouders zijn gezinsfactoren die samenhangen met delinquent gedrag (Loeber \& Stouthamer-Loeber, I986). Het meeste onderzoek richtte zich op het opvoedingsgedrag van de moeders en niet op de opvoeding door de vaders. Het is van belang om onderzoek te doen naar opvoeding door vaders en delinquent gedrag.

Ten eerste zijn er verschillen in de manier van opvoeden tussen vaders en moeders. Niet alleen de kwantiteit van de vader-kindinteracties verschilt; er zijn ook kwalitatieve verschillen. Vaders hebben bijvoorbeeld de neiging om meer instrumentele zorg te geven, terwijl moeders zich meer richten op emotionele zorg (Youniss \& Smollar, I985). Ten tweede blijkt uit onderzoek dat het gedrag van vaders delinquent gedrag bij zonen kan voorspellen. Het aantal keren dat vaders werden gearresteerd was de sterkste voorspeller van delinquent gedrag van zonen, vergeleken met het aantal arresten van andere gezinsleden (Farrington, Jolliffe, Loeber, Stouthamer-Loeber \& Kalb, 200I). Het is zelfs zo dat hoe langer antisociale vaders binnen het gezin blijven wonen, des te groter het risico dat de kinderen ook antisociaal gedrag gaan vertonen (Jaffee, Moffitt, Caspi \& Taylor, 2003). Mogelijke vertonen deze vaders problematisch opvoedingsgedrag, zoals hard straffen of weinig toezicht houden.

Ondanks deze eerdere bevindingen en mogelijke invloed van vaders, is er nog maar weinig onderzoek gedaan naar opvoeding door vaders in relatie tot gedrag van het kind. In het huidige onderzoek analyseren we dan ook de opvoeding van zowel de moeder als de vader, in relatie tot het delinquente gedrag van hun zonen en dochters.

\section{Opvoedingsstijlen}

De meeste studies naar het verband tussen opvoeding en delinquent gedrag zijn uitgegaan van de risicofactorbenadering ('risk factor approach'). In dit onderzoek staan variabelen centraal. Verschillen tussen gezinnen worden geïdentificeerd door middel van hun scores op afzonderlijke aspecten van opvoeding, zoals de mate van straffen, de mate van toezicht houden en de hoeveelheid genegenheid die ouders tonen aan hun kind. Een aantal onderzoekers heeft echter gepleit voor een typologische benadering, omdat deze meer geschikt is om een complex systeem zoals het gezin te onderzoeken (o.a. Mandara, 2003).

Een belangrijke typologie die zich richt op de opvoeding, is ontwikkeld door Maccoby en Martin (1983). Deze onderzoekers definieerden een viertal opvoedingsstijlen, aan de hand van een tweedimensionaal raamwerk, bestaande uit $a$ ondersteuning of warmte, en $b$ controle of disciplinering. De opvoedingsstijlen zijn: autoritatief (veel ondersteuning en veel controle), autoritair (weinig ondersteuning en veel controle), permissief (veel ondersteuning en weinig controle) en verwaarlozend (weinig ondersteuning en weinig controle). Opvoedingsstijlen zijn niet domeinspecifiek; dus deze zijn niet situatieafhankelijk (Darling \& Steinberg, I993).

Eerder onderzoek wijst erop dat met name een verwaarlozende stijl samenhangt met delinquent gedrag (Steinberg, Lamborn, Darling, Mounts \& Dornbusch, I994). Een multidimensionale benadering doet meer recht aan de complexiteit en veelzijdigheid van het opvoeden. Deze kan daardoor een uitgebreider begrip van de invloed van 
patronen van opvoeding op de ontwikkeling van delinquent gedrag opleveren, dan op zichzelf staande opvoedingskenmerken die meestal worden onderzocht als potentiële risicofactoren voor delinquentie. Eerder onderzoek naar opvoedingsstijlen richtte zich veelal op de opvoedingsstijl van beide ouders samen of alleen die van de moeder, waardoor onduidelijk is wat de invloed is van opvoedingsstijlen van vaders op delinquent gedrag.

\section{Doel van dit onderzoek}

Samenvattend kan worden gesteld dat het onderzoek naar sekseverschillen in risicofactoren voor delinquent gedrag schaars is. Bovendien is er weinig onderzoek gedaan naar opvoedingsstijlen in relatie tot delinquent gedrag en naar de invloed van opvoeding door vaders op het delinquente gedrag van hun kinderen.

In het huidige onderzoek richten we ons op de volgende onderzoeksvragen:

I Zijn er sekseverschillen in delinquent gedrag?

2 Zijn er sekseverschillen in opvoeding? Met andere woorden, worden jongens op een andere manier opgevoed dan meisjes?

3 Zijn er sekseverschillen in het verband tussen opvoeding en delinquent gedrag?

We onderzoeken cross-sectionele verbanden, waarbij opvoeding en delinquent gedrag op hetzelfde meetmoment tijdens de adolescentie zijn gemeten. Daarnaast onderzoeken we of er longitudinale verbanden bestaan. We analyseren of de opvoedingsstijl van ouders tijdens de adolescentieperiode van invloed is op het delinquente gedrag van de jongere op latere leeftijd, dat wil zeggen, wanneer de jongere jongvolwassen is geworden. We controleren hierbij voor eerder delinquent gedrag dat gemeten is tijdens de adolescentie, zodat we conclusies kunnen trekken over de causaliteit en over lange-termijneffecten van opvoedingsstijl op delinquent gedrag.

\section{Methode}

\section{Steekproef en procedure}

Voor dit onderzoek is gebruik gemaakt van het Nijmeegs Longitudinaal Gezinsonderzoek. Tijdens de eerste meting in I990 zijn gegevens verzameld van 788 gezinnen. De steekproef is representatief voor de Nederlandse bevolking wat betreft urbanisatiegraad en spreiding over de provincies (Gerris e.a., I993). Jongens en meisjes in de leeftijd van 9-16 jaar namen deel aan de studie. De tweede meting vond vijf jaar later plaats (in 1995). Aan deze meting namen 484 gezinnen deel. De derde meting vond plaats in 2000 . Hieraan namen 30I jongvolwassenen deel. De dataverzameling vond in het huis van het gezin plaats. Elk gezinslid werd individueel geïnterviewd. Tegelijkertijd werden vragenlijsten door de andere gezinsleden ingevuld.

Voor de analyses werden de gegevens uit de tweede en derde meting gebruikt, omdat tijdens deze metingen gegevens over delinquent gedrag waren verzameld. Omdat we de opvoeding van zowel vaders als moeders onderzochten in relatie tot delinquent gedrag bij hun kinderen, selecteerden we 330 jongeren die thuis woonden met hun beide ouders tijdens de tweede meting. De leeftijd van de jongeren varieerde van I3-22 
jaar, met een gemiddelde leeftijd van I7.2. Slechts een klein percentage jongeren was in het buitenland geboren of had ten minste één ouder die in het buitenland was geboren (6.7\%). Het gemiddelde gezinsinkomen was I.373 euro per maand.

\section{Meetinstrumenten}

In tegenstelling tot eerdere studies naar opvoedingsstijlen, die doorgaans a priori opvoedingsstijlen vaststellen aan de hand van subjectieve 'cut-off scores', maakten we gebruik van clusteranalyse - een multivariate techniek - om opvoedingsstijlen te identificeren in de data. De ouders werden gegroepeerd op basis van hun scores op uiteenlopende aspecten van opvoeden: gehechtheid, autonomie, conformiteit, straffen, negeren en responsiviteit. Deze aspecten van opvoeding werden gemeten tijdens de tweede meting (adolescentie tot vroege jongvolwassenheid) en representeren beide opvoedingsdimensies van warmte en controle (Maccoby \& Martin, I983).

- Gehechtheid representeerde de emotionele nabijheid van de ouder naar de jongere, en het vermogen om de gevoelens en behoeften van het kind waar te nemen en te begrijpen (negen items, alleen rapportage door de ouders; De Brock, Vermulst, Gerris, \& Abidin, I992).

- Autonomie was gedefinieerd als de ouderlijke aanmoediging bij de jongere van zelfstandigheid en zelfverantwoordelijkheid (zeven items, alleen rapportage door de ouders; Maccoby, I980).

- Bij conformistische opvoeding ging het om de mate waarin de ouders in de opvoeding van het kind de nadruk leggen op en waarde hechten aan conformiteit en aanpassing aan vaste regels, sociale normen en gewoonten (acht items gerapporteerd door de ouder, vier items gerapporteerd door de jongere; Baumrind, I967).

- Straffen was gedefinieerd als de mate waarin de ouder aangeeft in de opvoeding gebruik te maken van verschillende strafmaatregelen (vijf items, rapportage door ouder en jongere; Gerris \& Janssens, I987).

- Negeren verwees naar de mate waarin de ouder reageert met zowel boosheid als negeren, wanneer de jongere iets doet wat niet mag (vijf items, rapportage door ouder en jongere; Gerris \& Janssens, I987).

- Responsiviteit refereerde aan de mate waarin de jongere in de opvoeding responsiviteit ervaart voor behoeften, signalen en problemen (acht items, gerapporteerd door de jongere; Maccoby \& Martin, I983).

Wanneer de jongere rapporteerde over een opvoedingsaspect, dan beantwoordde hij of zij de vragen afzonderlijk voor de vader en de moeder. De interne consistentie van de opvoedingsschalen waren toereikend: de gemiddelde Cronbachs alfa was .8I en de alfa's varieerden van .65 voor autonomie (gerapporteerd door de moeder) tot .93 voor responsiviteit door de vader (gerapporteerd door de jongere). Wanneer er scores op een opvoedingsvariabele beschikbaar waren van zowel de jongere als de ouder, dan gebruikten we het gemiddelde van beide scores. Voor elke opvoedingvariabele waren hierdoor uiteindelijk twee scores beschikbaar: een score die betrekking had op de vader en score die betrekking had op de moeder.

Delinquent gedrag werd gemeten met een aangepaste versie van de standaard ISRDvragenlijst voor de International Self-Report Delinquency Study (ISRD Working Group, 
2005; Junger-Tas, Terlouw \& Klein, I994). Jongeren rapporteerden tijdens de tweede meting de mate van delinquent gedrag gedurende hun hele levensloop. De vragenlijst bevatte uiteenlopende delinquente gedragingen, variërend van vandalisme en kleine diefstallen tot mishandeling en verkrachting ( 28 items). De vragen hadden de volgende structuur: 'Hoe vaak heb je [delinquente activiteit]?' Er waren zeven antwoordcategorieën ( $\mathrm{I}=$ nooit; $2=$ ooit; $3=$ een paar keer tot nu toe; 4 = één tot een paar keer per jaar; 5 = één tot een paar keer per maand; 6 = één tot een paar keer per week; $7=$ één tot een paar keer per dag). Delinquent gedrag, gemeten op tijdstip 3, had betrekking op het laatste jaar. De vragen hadden de volgende structuur: 'Hoe vaak heb je [delinquente activiteit] in het afgelopen jaar?’ (veertig items, geen antwoordcategorieën).

In de analyses werd een aantal controlevariabelen gebruikt. Omdat de leeftijd van de jongeren sterk varieerde (13-22 jaar) werd leeftijd als covariaat toegevoegd aan de analyses. Daarnaast controleerden we voor het gezinsinkomen. Een lage sociaal-economische status blijkt namelijk samen te hangen met delinquent gedrag (zie o.a. Heimer, I997).

\section{Analyse van selectieve uitval en clusteranalyses}

De eventuele effecten van selectieve uitval werden onderzocht door het analyseren van demografische kenmerken, opvoedingsvariabelen en delinquentie. Met betrekking tot twee demografische variabelen vonden we selectieve uitval: leeftijd en urbanisatiegraad. Relatief meer oudere jongeren en jongeren uit de grote steden waren uitgevallen. Dit had geen invloed op de overgrote meerderheid van de opvoedingsvariabelen en delinquent gedrag (voor details over deze analyses zie Hoeve, 2008).

Voor de identificatie van opvoedingsstijlen werden clusteranalyses gedaan op de opvoedingsvariabelen (hiërarchische clusteranalyse en $k$-means). Voor de vader en moeder werden aparte clusteranalyses gedaan aan de hand van visuele methoden, zoals inspectie van het dendrogram en de agglomeratieschema's, en meer formele methoden zoals 'confirmatory cluster analysis' (Henry, Tolan \& Gorman-Smith, 2005; Mandara, 2003) en de cross-validatie procedure zoals beschreven door Mandara (2003). Op basis van de meest opvallende opvoedingskenmerken gaven we de volgende labels aan de clusters: autoritatief (IO9 moeders en Ioo vaders), autoritair (ondersteunend; 75 moeders en 89 vaders), permissief (weinig responsief; 74 moeders en 68 vaders) en verwaarlozend (bestraffend; 64 moeders en 27 vaders).

- Autoritatieve vaders en moeders hadden een goede vertrouwensrelatie met hun kind, en waren responsief naar de behoeften en signalen van hun kind. Zij straften hun kind minder vaak dan ouders met een andere opvoedingsstijl, maar hechtten wel veel waarde aan conformiteit van hun kind aan regels en sociale normen.

- Autoritaire (ondersteunende) ouders scoorden middelmatig op gehechtheid, waren responsief naar hun kind en rapporteerden een relatief hoge mate van straffen en conformiteit in de opvoeding.

- Permissieve (weinig responsieve) ouders hadden middelmatige scores op gehechtheid en lage scores op responsiviteit. Deze ouders straften hun kind nauwelijks en hechtten vrij weinig waarde aan conformiteit.

- Verwaarlozende (bestraffende) ouders hadden de slechtste vertrouwensrelatie met hun kind, straften hun kind relatief vaak en negeerden hun kind vaak bij wijze van 
straf. Tegelijkertijd hechtten deze ouders weinig waarde aan conformiteit. Blijkbaar hadden zij andere redenen om hun kind te straffen dan dat zij aanpassing aan regels en sociale normen van belang achtten.

De opvoedingskenmerken in de clusters van vaders en moeders waren vrijwel gelijk. Daarom gebruikten we dezelfde labels voor de opvoedingsstijlen van vaders en moeders. Het enige verschil was dat permissieve vaders significant lager scoorden op autonomie dan autoritatieve vaders. Bij permissieve en autoritatieve moeders was de mate van autonomie vrijwel gelijk (voor details over de clusteranalyses zie Hoeve, 2008).

\section{Resultaten}

\section{Sekseverschillen in delinquent gedrag}

Net als in eerdere steekproeven bleken ook in deze nationale steekproef jongens meer delinquent gedrag te rapporteren dan meisjes, zowel tijdens de adolescentie tot vroege jongvolwassenheid (13-22 jaar, tweede meting, $t(324)=-7.48, p<.00 \mathrm{I}$ ) als tijdens de jongvolwassenheid (I8-27 jaar, derde meting, $t$ (I92) $=-2.65, p<.0 \mathrm{I}$ ). Omdat tijdens de tweede meting gebruik gemaakt is van antwoordcategorieën (zoals nooit, ooit, een paar keer tot nu toe) en er niet gevraagd is naar het precieze aantal delicten, is het moeilijk om te bepalen hoe vaak meisjes ten opzichte van jongens delicten pleegden. Tijdens de jongvolwassenheid (derde meting) is de prevalentie van delinquent gedrag over het afgelopen jaar bij jongens ruim zesmaal zo hoog als de prevalentie bij meisjes.

\section{Sekseverschillen in opvoedingsstijl}

Uit de analyses bleek dat vaders dezelfde opvoedingsstijl hanteren voor hun zonen en dochters (I3-22 jaar, tweede meting, $\chi^{2}(3)=2.88, p>$.IO). Bij moeders vonden we wel een sekseverschil in opvoedingsstijl ( $13-22$ jaar, tweede meting, $\left.\chi^{2}(3)=9.94, p<.05\right)$. Zo hanteerden de moeders van de meisjes vaker een autoritatieve stijl dan de moeders van jongens (40\% van de meisjes had een autoritatieve moeder, tegenover $26 \%$ van de jongens). Daarnaast hadden de moeders van meisjes minder vaak een permissieve opvoedingsstijl dan moeders van jongens (I $8 \%$ van de meisjes had een permissieve moeder, tegenover $29 \%$ van de jongens).

\section{Sekseverschillen in het verband tussen opvoedingsstijlen en delinquentie}

We gebruikten tweewegcovariantieanalyses (ANCOVA) met opvoedingsstijlen en geslacht van de jongere als factoren en delinquentie als afhankelijke variabele. In alle modellen controleerden we voor leeftijd en gezinsinkomen. In het longitudinale model controleerden we tevens voor eerder delinquent gedrag (gemeten op de tweede meting). Omdat er afhankelijkheid bestond tussen de opvoedingsstijlen van vaders en moeders $\left(\chi^{2}(9)=163.33, N=295, p<.001\right.$ ), was het niet gewenst om beide factoren in één model samen te brengen. Om deze reden deden we de analyses voor vaders en moeders apart.

Uit de cross-sectionele analyses (tweede meting) met de opvoedingsstijlen van moe- 
ders kwamen de volgende resultaten naar voren. Het hoofdeffect van opvoedingsstijlen van moeders op delinquentie, gemeten tijdens de tweede meting, was niet significant. Er werd wel een significant effect van geslacht gevonden op delinquent gedrag ( $F$ $(\mathrm{I} .289)=47.82, p<.00 \mathrm{I}, \eta^{2}=. \mathrm{I} 4$; zie tabel I). Er werden geen effecten van leeftijd en gezinsinkomen gevonden. We vonden de volgende trend: het interactie-effect van opvoedingsstijl en geslacht was bijna significant $\left(F(3.289)=2.26, p=.08, \eta^{2}=.02\right)$. We analyseerden daarom verschillen in delinquent gedrag tussen opvoedingsstijlen bij moeders apart voor jongens en meisjes. We vonden alleen bij meisjes een hoofdeffect van opvoedingsstijl op delinquentie $\left(F(3.159)=5.29, p<\right.$. OI $\left.\eta^{2}=.09\right)$.

Via contrasten ('planned simple contrasts') analyseerden we tussen welke opvoedingsstijlen meisjesdelinquentie significant verschilde. Hiervoor vergeleken we de autoritaire, permissieve en verwaarlozende stijlen met de autoritatieve stijl. We namen de autoritatieve stijl als uitgangspunt, omdat uit eerder onderzoek blijkt dat deze stijl gerelateerd is aan de minste gedrags- en aanpassingsproblemen bij jongeren (Maccoby \& Martin, I983). Het bleek dat delinquent gedrag significant vaker voorkwam bij meisjes met een permissieve moeder dan bij meisjes met een autoritatieve moeder ( $t$ $(374)=4 . \mathrm{I} 7, p<.00 \mathrm{I})$.

Het longitudinale model bestond uit de factoren opvoedingsstijl (meting 2) en geslacht van de jongere en de afhankelijke variabele delinquent gedrag (meting 3). Net als in de cross-sectionele analyses controleerden we voor de covariaten leeftijd en gezinsinkomen. Omdat we wilden weten wat het unieke effect is van opvoedingsstijl boven het delinquente gedrag van de jongere, controleerden we ook voor eerder delinquent gedrag, gemeten tijdens de tweede meting. Alle effecten in de longitudinale analyses met opvoedingsstijlen van moeders waren niet significant. Ook de covariaten leeftijd, gezinsinkomen en delinquentie, gemeten tijdens de tweede meting, bleken niet significant samen te hangen met delinquent gedrag, gemeten tijdens tijdstip drie.

Uit de cross-sectionele analyses (tweede meting) met de opvoedingsstijlen van vaders kwamen de volgende resultaten naar voren. Er werden significante hoofdeffecten gevonden op delinquent gedrag van opvoedingsstijlen van vaders $(F(3.270)=3.99, p<$ $\left..05, \eta^{2}=.04\right)$ en geslacht $\left(F(\mathrm{I} .270)=52 . \mathrm{I} 2, p<.001, \eta^{2}=. \mathrm{I} 6\right)$. Er werden geen significante effecten gevonden van leeftijd en gezinsinkomen. Nadere analyses lieten zien dat jongeren met permissieve vaders $(t(280)=2.15, p<.05)$ en verwaarlozende vaders $(t(280)=3.2 \mathrm{I}, p<. \mathrm{OI})$ significant hoger scoorden op delinquentie dan jongeren met autoritatieve vaders. Ook werd een interactie-effect gevonden van opvoedingsstijl en geslacht $\left(F(3.270)=4.04, p<.0 \mathrm{I}, \eta^{2}=.04\right)$. Het bleek dat jongens delinquenter waren wanneer zij een verwaarlozende vader hadden, en dat meisjes delinquenter waren wanneer zij een permissieve vader hadden (zie figuur I).

De longitudinale analyses met opvoedingsstijlen van vaders (meting 2) en delinquentie, gemeten vijf jaar later (meting 3), wezen uit dat het delinquente gedrag van de jongvolwassenen significant verschilde tussen de opvoedingsstijlen van vaders $(F$ $\left.(3.154)=3.08, p<.05, \eta^{2}=.06\right)$ en tussen zonen en dochters $(F($ I.I54) $=$ I4.62, $p<.00 \mathrm{I}$, $\eta^{2}=$.09). Er werden geen effecten gevonden van de covariaten leeftijd en gezinsinkomen. Ook vonden we geen effect van de controlevariabele eerder delinquent gedrag (meting 2). De geplande contrasten wezen uit dat jongeren met een verwaarlozende vader significant vaker delinquent gedrag vertoonden tijdens de jongvolwassenheid 
KIND EN ADOLESCENT | JAARGANG 30 (2009), NR. 2 | WWW.KINDENADOLESCENT.NL

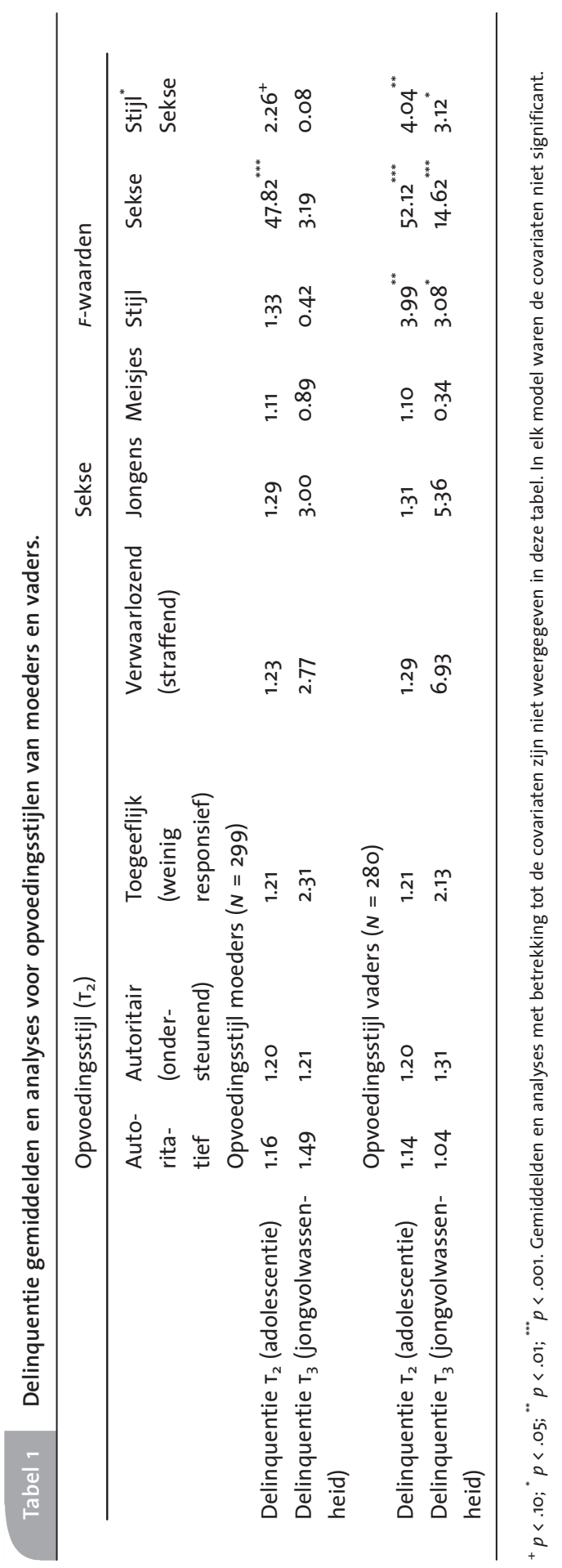


dan jongeren met een autoritatieve vader $\left(t\left(\mathrm{I}_{5}\right)=2.9 \mathrm{I}, p<.0 \mathrm{I}\right)$. Ook werd er een interactie-effect gevonden van opvoedingsstijl en geslacht $\left(F(3.154)=3.12, p<.05, \eta^{2}=\right.$ .o6): een verwaarlozende opvoedingsstijl bij vaders was gerelateerd aan een relatief hoge mate van delinquent gedrag bij jongvolwassen mannen, maar niet bij jongvolwassen vrouwen (zie figuur 2).

Figuur 1 Interactie-effect van de opvoedingsstijl van vaders en geslacht op delinquent gedrag, gemeten tijdens de tweede meting.

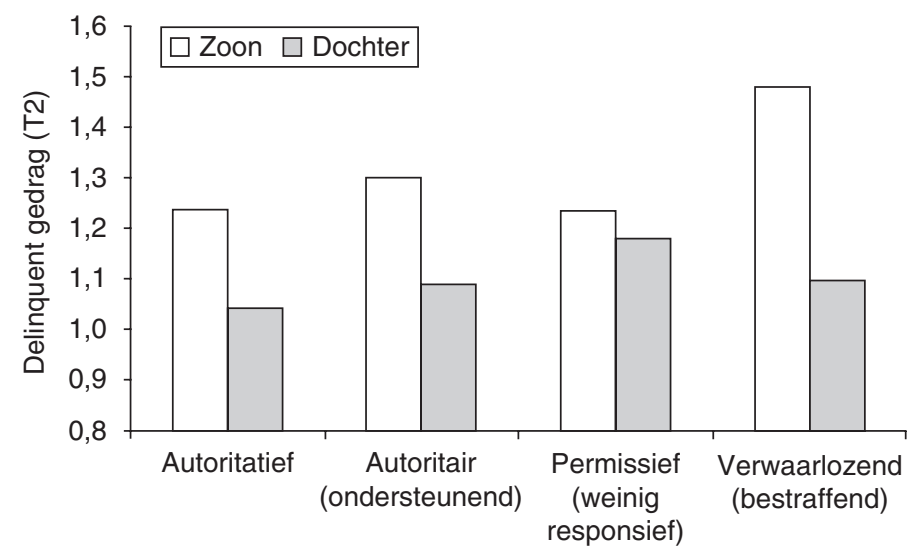

Opvoedingsstijl van de vader (T2)

Figuur 2 Interactie-effect van de opvoedingsstijl van vaders en geslacht op delinquent gedrag, gemeten tijdens de derde meting.

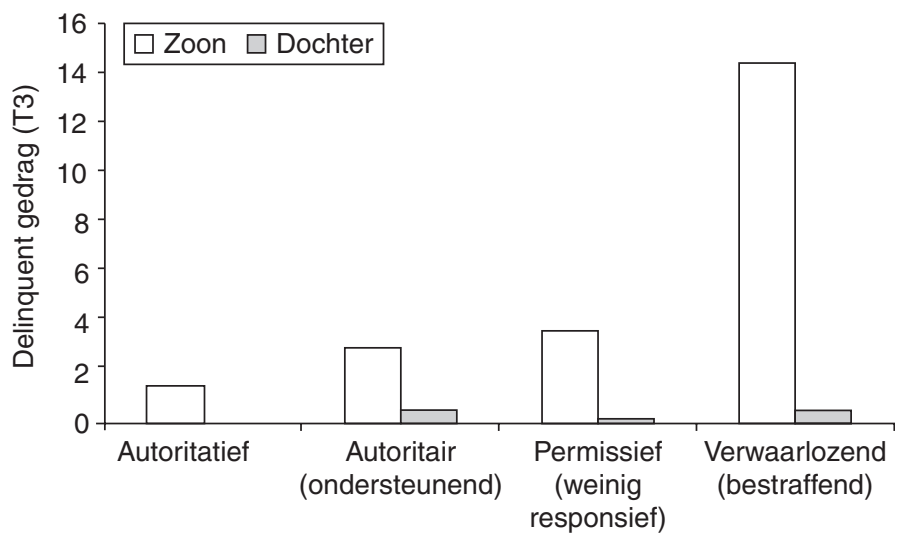

Opvoedingsstijl van de vader (T2) 


\section{Discussie}

In deze studie werd onderzocht of er sekseverschillen bestaan in opvoeding en delinquentie en in het verband hiertussen. Het onderzoek had betrekking op de opvoedingsstijlen van zowel moeders als vaders en was longitudinaal van aard. Net als in eerder onderzoek bleken jongens vaker delinquent gedrag te vertonen dan meisjes. Tijdens de jongvolwassenheid was het sekseverschil relatief groot: jongens gaven zesmaal zo vaak aan delicten te plegen dan meisjes. Dit is een relatief groot verschil vergeleken met sekseverschillen die bij adolescenten gevonden worden. Moffitt e.a. (200I) vonden ook dat relatief weinig meisjes ten opzichte van jongens het persistente traject volgen waarbij jongeren op latere leeftijd, na de adolescentie, doorgaan met het plegen van delicten.

In tegenstelling tot vaders bleken moeders verschillende opvoedingsstijlen te hanteren voor zonen en dochters. Dochters werden relatief vaker autoritatief opgevoed door moeders, en een autoritatieve opvoedingsstijl was gerelateerd aan de laagste delinquentiescores bij zonen en dochters. Dit sluit aan bij eerder onderzoek waarin sekseverschillen in de opvoeding werden gevonden. Zo bleek dat ouders vaker toezicht houden op meisjes (Svensson, 2003) en dat moeders relatief meer genegenheid uiten naar dochters vergeleken met zonen (Shepard \& Zboyan, I997). Mogelijk verklaart dit verschil in opvoeding een deel van het sekseverschil in delinquent gedrag.

We vonden ook een sekseverschil in het verband tussen opvoeding en delinquentie. Het bleek dat een verwaarlozende hard straffende opvoedingsstijl gerelateerd was aan delinquentie door jongens, terwijl een permissieve en weinig responsieve opvoedingsstijl samenhing met delinquentie bij meisjes. Deze bevinding sluit niet aan bij de hypothese dat jongens gevoeliger zijn voor inadequate opvoedingsstijlen dan meisjes. In het huidige onderzoek werd immers niet alleen bij jongens een verband tussen opvoedingsstijlen en delinquentie gevonden, maar ook bij meisjes. Echter, de opvoedingsstijlen die samenhingen met delinquent gedrag verschilden tussen jongens en meisjes.

Dit resultaat is van belang voor het debat dat onderzoekers sinds de jaren zeventig van de vorige eeuw voeren over de vraag of theorieën die delinquent gedrag trachten te verklaren, zowel van toepassing zijn op jongens- als op meisjesdelinquentie (zie bijv. Daigle, Cullen \& Wright, 2007). Klassieke criminologische theorieën zijn vrijwel altijd gebaseerd op kennis over de oorzaken van criminaliteit door jongens en mannen. Sommige onderzoekers pleiten voor seksespecifieke theorieën voor het verklaren van delinquent gedrag (bijv. Chesney Lind, 2006; Hagan, I999). Onze bevindingen sluiten aan bij het idee dat andere (opvoedings)factoren een rol spelen bij de ontwikkeling van delinquent gedrag en pleiten daarmee voor een seksespecifieke theorie. De resultaten zijn tevens van belang voor behandelprogramma's die gericht zijn op delinquente meisjes en hun opvoeders. Gezien het feit dat de huidige interventies voor delinquente jongeren gebaseerd zijn op de kennis over delinquentie bij jongens, is verder onderzoek van belang om meer inzicht te krijgen in de mechanismen die een rol spelen bij de ontwikkeling van delinquent gedrag bij meisjes (Hipwell \& Loeber, 2006).

Uit het huidige onderzoek kwam een aantal opvallende verschillen naar voren tussen opvoedingsstijlen van vaders en moeders in relatie tot delinquentie. Opvoedingsstijlen 
van vaders waren gerelateerd aan delinquentie bij zonen en dochters, terwijl opvoedingsstijlen van moeders alleen gerelateerd waren aan delinquentie bij dochters. Bovendien bleek een verwaarlozende stijl bij vaders van invloed op later delinquent gedrag tijdens de jongvolwassenheid bij zonen. We vonden namelijk een aanvullende voorspellende waarde van de verwaarlozende opvoedingsstijl van vaders boven de stabiliteit in delinquent gedrag. Omdat we in onze analyses controleerden voor eerder delinquent gedrag tijdens de adolescentie, kunnen we concluderen dat er een unieke bijdrage is van de verwaarlozende opvoedingsstijl van de vader in de verklaring van delinquent gedrag tijdens de jongvolwassenheid en dat dit verband niet wordt verklaard door eerder delinquent gedrag van de jongens. Dit betekent dat de opvoedingsstijl van vaders mogelijk langer van invloed is op delinquentie bij jongens dan bij meisjes. Deze resultaten laten zien dat het waardevol kan zijn wanneer de opvoedingsstijl van vaders aandacht krijgt binnen interventies die gericht zijn op delinquente jongens en meisjes.

\section{Tot besluit}

Uit de longitudinale analyses bleek dat delinquent gedrag tijdens de adolescentie niet samenhangt met delinquentie tijdens de jongvolwassenheid. Dit is tegenstrijdig met de resultaten uit eerder onderzoek waaruit blijkt dat delinquent gedrag een goede voorspeller is van toekomstig delinquent gedrag (bijv. Donker, Smeek, Van der Laan \& Verhulst, 2003). Het feit dat we in deze studie geen verband vonden tussen eerder en later delinquent gedrag, kan worden verklaard aan de hand van het theoretische model van Moffitt (I993). Deze maakt hierin onderscheid tussen 'adolescence-limited delinquents' en 'life-course persistent delinquents'. Bij de eerste groep blijft het delinquente gedrag beperkt tot de adolescentieperiode. Het gaat om een vrij grote groep jongeren die weinig problemen hebben ondervonden tijdens de kindertijd en die zich voornamelijk bezighouden met lichte delicten. De tweede groep begint al op jonge leeftijd met het vertonen van delinquent gedrag en gaat ook tijdens de (jong)volwassenheid door met het plegen van delicten.

Het gaat hier om een relatief kleine problematische groep. Wanneer de meerderheid van de jongeren, de groep 'adolescence-limited delinquents', tijdens de jongvolwassenheid is gestopt met het plegen van delicten en het delinquente gedrag tijdens de jongvolwassenheid is toe te schrijven aan de kleine groep 'life-course persistent delinquents', dan kan dit een verklaring bieden voor het feit dat wij geen verband vonden tussen delinquentie tijdens de adolescentie en later delinquent gedrag tijdens de jongvolwassenheid.

Dit onderzoek kent enkele beperkingen. De steekproef bestond uit jongeren die nog thuis woonden bij hun vader en moeder. De resultaten zijn hierdoor niet generaliseerbaar naar eenoudergezinnen en vaders die niet bij hun kind wonen. Eerder onderzoek heeft aangetoond dat kinderen van autoritatieve vaders die apart leven van hun gezin minder externaliserend probleem gedrag vertonen (Amato \& Gilbreth, I999). Dit impliceert dat vaders zelfs invloed hebben wanneer het contact met hun kinderen minder frequent is.

Een tweede beperking is dat er relatief weinig allochtone groepen in de steekproef 
voorkwamen. De resultaten zijn dan ook niet generaliseerbaar naar deze groepen. Bovendien willen we opmerken dat delinquent gedrag niet alleen een gevolg hoeft te zijn van de opvoedingsstijl van de ouder. Het omgekeerde kan ook gelden: de opvoedingsstijl van de ouders kan zijn beïnvloed door het delinquente gedrag van hun kind. De longitudinale analyses, waarbij we controleren voor eerder delinquent gedrag, laten echter zien dat er een unieke bijdrage is van de opvoedingsstijl van vaders in de verklaring van later delinquent gedrag bij zonen.

Ondanks de beperkingen heeft dit onderzoek ook enkele sterke punten. Het onderzoek was longitudinaal, richtte zich op zowel jongens als meisjes en moeders als vaders, maakte gebruik van meerdere informanten en gebruikte uiteenlopende aspecten voor het identificeren van opvoedingsstijlen. Dit onderzoek is een van de weinige studies naar delinquentie die beide ouders heeft betrokken bij de analyses. Samengevat resulteerde dit onderzoek in sekseverschillen in opvoeding en delinquentie en het verband hiertussen. Bovendien bleek dat de opvoedingsstijl van vaders sterker gerelateerd was aan delinquentie bij zonen dan de opvoedingsstijl van moeders.

\section{Literatuur}

Amato, P. R., \& Gilbreth, J. G. (I999). Nonresident fathers and children's well-being: A meta-analysis. Journal of Marriage and the Family, 61, 557-573.

Baumrind, D. (1967). Child care practices anteceding three patterns of preschool behavior. Genetic Psychology Monographs, 75, 43-88.

Canter, R. J. (1982). Family correlates of male and female delinquency. Criminology: An Interdisciplinary Journal, 20, I49-167.

Chesney Lind, M. (2006). Patriarchy, crime, and justice: Feminist criminology in an era of backlash. Feminist Criminology, 1, 6-26.

Daigle, L. E., Cullen, F. T., \& Wright, J. P. (2007). Gender differences in the predictors of juvenile delinquency: Assessing the generality-specificity debate. Youth Violence and Juvenile Justice, 5, 254-286.

Darling, N., \& Steinberg, L. (I993). Parenting style as context: An integrative model. Psychological Bulletin, 113, 487-496.

De Brock, A. J. L. L., Vermulst, A. A., Gerris, J. R. M., \& Abidin, R. R. (I992). Nijmeegse Ouderlijke Stress Index NOSI. Lisse: Swets and Zeitlinger.

Donker, A. G., Smeenk, W. H., Van der Laan, P. H., \& Verhulst, F. C. (2003). Individual stability of antisocial behavior from childhood to adulthood: Testing the stability postulate of Moffitt's developmental theory. Criminology, 41, 593-6ro.

Farrington, D. P., Jolliffe, D., Loeber, R., Stouthamer-Loeber, M., \& Kalb, L. M. (200I). The concentration of offenders in families, and family criminality in the prediction of boys' delinquency. Journal of Adolescence, $24,579-596$.

Gerris, J. R. M., \& Janssens, J. M. A. M. (1987). Opvoedingsgedrag van ouders in overtredingssituaties: Een onderzoek naar beïnvloedende factoren. Pedagogische Studiën, 64, 295-307.

Gerris, J. R. M., Vermulst, A. A., Van Boxtel, D. A. A. M., Janssens, J. M. A. M., Van Zutphen, R. A. H., \& Felling, A. J. A. (I993). Parenting in Dutch families: A representive description of Dutch family life in terms of validated concepts representing characteristics of parents, children, the family as a system and parental sociocultural value orientations. Nijmegen: Institute of Family Studies, University of Nijmegen. 
Hagan, J. (I999). A power-control theory of gender and delinquency. In F. T. Cullen \& R. Agnew (Eds.), Criminological theory: Past to present (pp. 199-206). Los Angeles: Roxbury.

Heimer, K. (I997). Socioeconomic status, subcultural definitions, and violent delinquency. Social Forces, 75, 799-833.

Henry, D. B., Tolan, P. H., \& Gorman-Smith, D. (2005). Cluster analysis in family psychology research. Journal of Family Psychology, 19, I2I-I32.

Hipwell, A. E., \& Loeber, R. (2006). Do we know which interventions are effective for disruptive and delinquent girls? Clinical Child and Family Psychology Review, 9, 22I-255.

Hoeve, M. (2008). Parenting and juvenile delinquency. (Ongepubliceerde dissertatie.) Nijmegen: Radboud Universiteit.

ISRD Working Group. (2005). Questionnaire ISRD-2: Standard Student Questionnaire. Utrecht: Verwey-Jonker Instituut.

Jaffee, S. R., Moffitt, T. E., Caspi, A., \& Taylor, A. (2003). Life with (or without) father: The benefits of living with two biological parents depend on the father's antisocial behavior. Child Development, 74, I09-126.

Junger-Tas, J., Terlouw, G.-J., \& Klein, M. W. (I994). Delinquent behavior among young people in the western world. Amsterdam: Kugler.

Lenssen, S. A. M., Doreleijers, T. A. H., Van Dijk, M. E., \& Hartman, C. (2000). Girls in detention: What are their characteristics? A project to explore and document the character of this target group and the significant ways in which it differs from one consisting of boys. Journal of Adolescence, 23, 287-303.

Loeber, R., \& Stouthamer-Loeber, M. (I986). Family factors as correlates and predictors of juvenile conduct problems and delinquency. In M. H. Tonry \& N. Morris (Eds.), Crime and justice: An annual review of research (Vol. 7, pp. 29-I49). Chicago: University of Chicago Press.

Maccoby, E. E. (I980). Social development: Psychological growth and parent-child relationship. New York: Harcourt Brace Jovanovich.

Maccoby, E. E., \& Martin, J. A. (1983). Socialization in the context of the family: Parent-child interaction. In P. H. Mussen (Ed.), Handbook of child psychology: Socialization, personality and social development (Vol. IV, pp. I-IOI). New York: Wiley.

Mandara, J. (2003). The typological approach in child and family psychology: A review of theory, methods, and research. Clinical Child and Family Psychology Review, 6, I29-I46.

McFadyen Ketchum, S. A., Bates, J. E., Dodge, K. A., \& Pettit, G. S. (I996). Patterns of change in early childhood aggressive-disruptive behavior: Gender differences in predictions from early coercive and affectionate mother-child interactions. Child Development, 67, 24I7-2433.

Ministerie van Justitie (2008). 2007 Jaarbericht Openbaar Ministerie in cijfers. Den Haag: Ministerie van Justitie.

Moffitt, T. E. (I993). Adolescence-limited and life-course-persistent antisocial behavior: A developmental taxonomy. Psychological Review, 100, 674-701.

Moffitt, T. E., Caspi, A., Rutter, M., \& Silva, P. A. (200I). Sex differences in antisocial behaviour: Conduct disorder, delinquency, and violence in the Dunedin Longitudinal Study. New York: Cambridge University Press.

Shepard, B. A., \& Zboyan, H. A. (1997). Parent-child relationships during middle childhood: Gender differences in interaction. (Paper, Biennial Meeting of the Society for Research in Child Development, Washington, DC.)

Steinberg, L., Lamborn, S. D., Darling, N., Mounts, N. S., \& Dornbusch, S. M. (I994). Over-time changes in adjustment and competence among adolescents from authoritative, authoritarian, indulgent, and neglectful families. Child Development, 65, 754-770.

Svensson, R. (2003). Gender differences in adolescent drug use: The impact of parental monitoring and peer deviance. Youth and Society, 34, 300-329. 
KIND EN ADOLESCENT | JAARGANG 30 (2009), NR. 2 | WWW.KINDENADOLESCENT.NL

Van der Laan, A. M., \& Blom, M. (2006). Jeugddelinquentie: risico's en bescherming. Den Haag: Boom. Webster Stratton, C. (I996). Early onset conduct problems: Does gender make a difference? Journal of Consulting and Clinical Psychology, 64, 540-551.

Youniss, J., \& Smollar, J. (1985). Adolescent relations with mothers, fathers, and friends. Chicago: University of Chicago Press. 